\section{artelogie}

\section{Artelogie}

Recherche sur les arts, le patrimoine et la littérature de l'Amérique latine

$12 \mid 2018$

Idiosyncrasie de l'indigénisme en Amérique latine.

Pluralité des sources et des appropriations extra-

latino-américaines

\title{
Perspectivas del indígena en el Manifiesto del Sindicato de Obreros, Técnicos, Pintores y Escultores
}

Sureya Alejandra Hernández del Villar

\section{QpenEdition \\ Journals}

Edición electrónica

URL: http://journals.openedition.org/artelogie/2039

DOI: 10.4000/artelogie.2039

ISSN: 2115-6395

Editor

Association ESCAL

Referencia electrónica

Sureya Alejandra Hernández del Villar, « Perspectivas del indígena en el Manifiesto del Sindicato de Obreros, Técnicos, Pintores y Escultores », Artelogie [En línea], 12 | 2018, Publicado el 07 septiembre 2018, consultado el 10 diciembre 2020. URL : http://journals.openedition.org/artelogie/2039 ; DOI : https://doi.org/10.4000/artelogie.2039

Este documento fue generado automáticamente el 10 diciembre 2020.

Association ESCAL 


\title{
Perspectivas del indígena en el Manifiesto del Sindicato de Obreros, Técnicos, Pintores y Escultores
}

\author{
Sureya Alejandra Hernández del Villar
}

1 El Sindicato de Obreros, Técnicos, Pintores y Escultores (SOTPE) fue integrado por el grupo de pintores muralistas que decoraron los muros de la Escuela Nacional Preparatoria (Antiguo Colegio de San Ildefonso) y la Secretaría de Educación Pública (SEP) entre 1922 y 1924. Los pintores sindicalizados (más en el discurso que en la práctica, pues el sindicato no tuvo efectividad como tal) publicaron textos programáticos que exponían, en la línea de los manifiestos de vanguardia, los escenarios posibles que vislumbraban para el arte mexicano. Éste debía ser asequible a las masas, revolucionario, monumental, un bien público y "una finalidad de belleza para todos, de educación y de combate". ${ }^{1}$ Imaginaban al artista como obrero, intelectual y revolucionario; un sujeto activo, movilizador de conciencias y en diálogo con la sociedad desde la trinchera del arte. El perfil del artista se dibujaba en relación con otros actores que sustentaban sus planteamientos, sujetos increpados, inquiridos, interpelados, denostados o reivindicados. Combatían al burgués y al "contrarrevolucionario" y llamaban al obrero, al campesino y al indígena.

Citado hasta el hartazgo, el Manifiesto del Sindicato de Obreros, Técnicos, Pintores y Escultores (en adelante Manifiesto del SOTPE) ha sido un documento imprescindible en las narraciones sobre el Muralismo Mexicano. La consigna de socializar el arte, así como la apuesta por el arte monumental y el repudio a la pintura de caballete ha permitido explicar, desde lo postulado en el manifiesto, las propuestas de los pintores muralistas. Por supuesto, las premisas de los manifiestos artísticos no establecieron pautas que debían seguirse con rigor. Su lectura puede analizarse como un correlato de las obras generadas en diálogo con sus proposiciones, pero representan por sí mismos productos estéticos y gestos críticos de contenido literario, visual e incluso performativo, cuya enunciación ha movilizado el mundo del arte. 
3 Varios son los problemas abordados por el SOTPE en su manifiesto, pero uno de los principales radicaba en la interpretación del indígena. El Manifiesto del SOTPE fue publicado en como una proclama tanto estética cuanto política a través de la cual los artistas definían vías para el arte y se pronunciaban respecto a las contingencias políticas de su momento. En las siguientes líneas se describirá cómo era interpretado el indígena con base en estos dos lineamientos discursivos. El Manifiesto del SOTPE se inscribía, por un lado, en un debate que conformó, designó y denominó al indígena como un singular colectivo a través de proyectos políticos y disertaciones de intelectuales que lo recuperaban como un sujeto insoslayable en la dilucidación de "lo mexicano". Pero también se ajustaba a la dinámica de las vanguardias latinoamericanas perfiladas con base en una distinción fincada a menudo en el paroxismo de "lo propio", la valoración de lo popular y el "retorno a los orígenes", lo cual implicaba una selección e interpretación del pasado y del devenir de las sociedades dentro de las cuales se reconocían los artistas de vanguardia.

\section{El Manifiesto del Sindicato de Obreros, Técnicos, Pintores y Escultores.}

49 de diciembre de 1923. El Sindicato de Obreros, Técnicos, Pintores y Escultores irrumpió en las calles de la Ciudad de México con un manifiesto que clamaba por la socialización del arte y condenaba la rebelión delahuertista. El documento apareció suscrito por David Alfaro Siqueiros como secretario general, Diego Rivera como primer vocal y Xavier Guerrero como segundo vocal. Incluyó también como firmantes a José Clemente Orozco, Fermín Revueltas, Ramón Alva Guadarrama, Germán Cueto y Carlos Mérida, aunque entre los miembros del sindicato se contaron también otros artistas como Fernando Leal, Jean Charlot, Roberto Montenegro, Amado de la Cueva, Roberto Reyes Pérez, Emilio García Cahero, Manuel Anaya, Máximo Pacheco, Ramón Alva de la Canal, Nahui Ollin, Carmen Foncerrada e Ignacio Asúnsolo. ${ }^{2}$

5 El texto fue redactado por Siqueiros pero no consignaba su autoría, pues representaba la voz colectiva del sindicato y señalaba un programa que legitimaba el proyecto pictórico que compartía el grupo de artistas. Sin embargo, considerar la autoría de Siqueiros resulta fundamental para la lectura del Manifiesto del SOTPE y las interpretaciones que del indígena que se elaboraron a través de éste. Como antecedente de este manifiesto hay que señalar otro texto programático realizado por Siqueiros en 1921: 3 llamamientos de orientación actual a los pintores y escultores de la nueva generación americana, en el cual reivindicaba el elemento indígena como un componente fundante de una nueva estética. Por otro lado, en el Manifiesto del SOTPE se reflejaba también la propia experiencia del Muralismo Mexicano, aún en el albor, pero que ya contaba con un repertorio visual que había llevado imágenes del indígena a los edificios públicos.

6 Los pintores trabajaban en los proyectos murales antes de la proclamación de su programa estético y desde diciembre de 1922 se había anunciado la organización del sindicato. ${ }^{3}$ Un año después, una coyuntura política los animó a tomar una postura que delineaba adscripciones, alianzas y simpatías. Publicaron el manifiesto como reacción al estallido de la rebelión delahuertista, un levantamiento armado liderado por Adolfo de la Huerta en contra de Álvaro Obregón (entonces presidente de México) y Plutarco Elías Calles (candidato oficial para las elecciones presidenciales de 1924). Se trataba de una 
disputa por el poder y la sucesión presidencial que mantenía el tono de los enfrentamientos entre caudillos revolucionarios. Los artistas se situaron del lado de lo que consideraban "la revolución más ideológicamente organizada" representada por la facción de Obregón y Calles, mientras que condenaban a la burguesía armada y contrarrevolucionaria personificada por de la Huerta. Procuraron, sin éxito, estar prestos para tomar las armas, y se hicieron de un raquítico arsenal adquirido por Xavier Guerrero, cuyo deplorable estado más bien amenazaba con ser fatal para quien lo empuñara. ${ }^{4}$ Por fortuna y el bien de los artistas, su ímpetu revolucionario detonó sólo en aquellos muros en los cuales colocaron, a manera de cartel, su manifiesto, distribuido también como hoja volante entre un público incauto. ${ }^{5}$

7 En julio de 1924, pocos días antes de que se efectuara la elección presidencial, el SOTPE publicó de nueva cuenta el manifiesto en su órgano de difusión, el periódico El Machete, refrendando con ello la adscripción a la candidatura de Calles y el proyecto político que representaba. El Manifiesto del SOTPE enfilaba a los artistas en el fuego de una batalla que se antojaba ajena a su campo y entretejía eventos políticos coyunturales con un programa artístico.

Los lindes entre el manifiesto artístico y el manifiesto político son escurridizos, debido a que el primero procede del segundo. Para Martin Puchner, la historia del manifiesto es aquella que narra la "lucha" sobre la relación entre arte y política, ${ }^{6}$ elementos imbricados en los textos programáticos que de acuerdo con la agenda vanguardista de aproximar el arte a la praxis vital involucró a los artistas con espacios y problemáticas que rebasaban y cuestionaban las fronteras de la institución "arte". ${ }^{7}$

9 Para Renato González Mello, el Manifiesto de SOTPE se inscribe "con pleno derecho" entre los documentos de vanguardia, e incluso asegura que se trata de uno de los pocos textos "realmente vanguardistas" producidos en México, no obstante esto haya sido opacado por la oficialización de la pintura mural que diluyó el sentido contestatario del movimiento pictórico. Además, González Mello afirma que en el caso mexicano las agrupaciones de artistas e intelectuales se aglutinaron como "generaciones", las cuales incorporaban a una juventud activa dispuesta a marcar la pauta y "tomar las riendas", en contraste con las vanguardias "iluminadas y marginales". 8

10 De acuerdo con Mari Carmen Ramírez las vanguardias latinoamericanas invirtieron los paradigmas de la vanguardia europea y pusieron énfasis en la función social y la dimensión política del arte. Además establecieron un "regreso al pasado" a partir del cual las culturas ancestrales fungían como elementos inclusivos de las masas y "vitalizadoras de la modernidad", perspectivas contrastantes con los postulados de "no participación" y "anti-tradición" propios del dadaísmo y el futurismo. ${ }^{9}$ Por su parte, Viviana Gelado señala que la valoración que la vanguardia hizo de lo popular significó un cuestionamiento al arte como institución que funcionaba desde la periferia de su propia cultura y operaba en dirección hacia el centro. Para Gelado, la apropiación de elementos temáticos y formales implicaba la confluencia de discursos culturales. ${ }^{10}$ Es además en los manifiestos que Gelado encuentra expresadas estas características de la vanguardia latinoamericana y observa que principalmente en los casos de México y Perú se realizó una valoración de lo popular a través del indigenismo y la inclusión, -con base en la noción de renacimiento-, de elementos prehispánicos. ${ }^{11}$ Precisamente, el Muralismo Mexicano se ha explicado a partir de la categoría "renacimiento", en una relación por analogía que asociaba la experiencia mexicana con el Renacimiento Italiano y, entre otras cosas, comparaba la 
mirada que los muralistas dirigieron hacia el pasado prehispánico con el acercamiento de los renacentistas hacia los vestigios grecorromanos. ${ }^{12}$

11 El Manifiesto del SOTPE planteaba una diacronía a la manera de las vanguardias latinoamericanas. Por un lado deponía una tradición representada por el arte como institución, con lo cual negaba un pasado inmediato, erigido como tal al ser sustituido con una alternativa, una salida distinta para los nuevos problemas sugeridos, discordes con una estética cuya caducidad se proclamaba con la inauguración de un arte renovado. Renovado pero no precisamente inédito. Desdeñaba una tradición encerrada en los límites del arte como campo auto regulado y mostraba una apertura hacia otra que respondía a una exégesis del origen fincado en el elemento indígena. La pintura mural, el arte público y "la socialización de las manifestaciones artísticas" representaban la alternativa a la pintura de caballete rechazada por burguesa. Los muralistas revitalizaron la antigua técnica del fresco, hurgando en tratados de pintura, experimentando con la baba del nopal y apelando a los antecedentes históricos de la pintura mural en México. Contaban con referentes tanto prehispánicos como coloniales, aunque en el discurso ponderaron los primeros. ${ }^{13}$

(...) el arte del pueblo de México es la manifestación espiritual más grande y más sana del mundo y su tradición indígena es la mejor de todas. $Y$ es grande precisamente porque siendo popular es colectiva, y es por eso que nuestro objetivo fundamental radica en socializar las manifestaciones artísticas tendiendo hacia la desaparición absoluta del individualismo burgués. ${ }^{14}$

12 El arte imaginado en el manifiesto era popular, colectivo y social. Tales características conllevaban que los artistas realizaran una especie de taxonomía del pueblo, en el cual se contaba al indígena. Al elogiar el arte del pueblo de México y aspirar a la conformación de una estética mexicana cuya originalidad radicara precisamente en el vínculo que ésta debía mantener con su particular entorno social, los artistas describieron aquello que concebían como fuente y destino de las proposiciones vertidas en el manifiesto. El indígena asumía un papel protagónico, como uno de los principales ejes de la estética propuesta y como un elemento que dotaba de especificidad al arte mexicano. Los artistas se declararon del lado de la revolución social y en contra de la burguesía; rechazaron la pintura de caballete a favor del arte público y monumental con un objetivo pedagógico a favor de las clases trabajadoras. El arte debía provenir de una estética popular y la valoración de la tradición indígena. ${ }^{15}$

13 Con un tono crítico, elegíaco y apologético, el Muralismo Mexicano proyectó imágenes que presentaban al indígena como monumento, en sintonía con un relato historiográfico que glorificaba el pasado prehispánico y observaba al indígena como un elemento identitario y definitorio de la mexicanidad. En los murales se incluyeron caracterizaciones fenotípicas, representaciones de tradiciones populares -principalmente dancísticas- e interpretaciones históricas expuestas de manera visual que empataban con el discurso reivindicador del indígena vertido en el manifiesto.

14 Las obras de los muralistas y el manifiesto del sindicato pueden articularse como un correlato que presentaba distintos puntos de vista dentro de una misma escena. Sin duda hay una resonancia entre las proposiciones de la pintura y el texto programático. Cabe señalar que algunos de los murales que desarrollaron esta temática fueron realizados antes de la proclamación del manifiesto. Tal es el caso de Masacre en el Templo Mayor de Jean Charlot o Alegoría de la Virgen de Guadalupe de Fermín Revueltas -con Máximo Pacheco como ayudante-, pintados en la Preparatoria. O los murales -también de Jean Charlot- La 
danza de los listones y Cargadores, pintados en la SEP, al igual que la poesía náhuatl traducida al español y colocada en las sobrepuertas de las obras de Diego Rivera que decoraron los muros de la planta baja del Patio del Trabajo de la SEP. ${ }^{16}$

La representación del indígena no era inédita sino que se había incluido en las imágenes nacionalistas que desde el siglo XIX habían encumbrado una época de oro vislumbrada en el pasado prehispánico. Sin embargo, ahora la vertiente indigenista del arte ponderaba sobre la pintura de historia las visiones antropológicas y los referentes arqueológicos que hacían fehaciente la monumentalidad de la antigüedad. A través del Muralismo las deidades prehispánicas y las festividades populares indígenas encontraron su sitio dentro del arte moderno, así como los relatos del choque entre culturas dispares que encajaron en un nuevo artificio que el discurso nacionalista se esmeraba en definir dentro de una continuidad histórica. ${ }^{17}$

16 Allende los muros, aunque sin olvidarlos, lo enunciado en el Manifiesto del SOTPE problematizaba al indígena de una manera particular de acuerdo con las características del medio. Los lineamientos discursivos políticos y estéticos del texto programático le otorgan a las perspectivas sobre el indio un matiz que transita entre la amplitud semántica del concepto, la denuncia, la arenga y la reivindicación de una raza humillada.

\section{"A la raza indígena humillada"}

17 Cada manifiesto es enunciativo y apelativo, expresa proposiciones y llama a un interlocutor que se imagina como un eco, pues los sujetos interpelados se constituyen con base en la manera en que se conciben aquellos que enuncian. El manifiesto artístico recurre al género epistolar, identifica a su audiencia y se dirige a ella de manera explícita, aunque ésta se muestre ambigua en la amplitud de las categorías generales. ${ }^{18} \mathrm{En}$ el caso del Manifiesto del SOTPE los artistas se dirigían, en primera instancia, "a la raza indígena humillada". De este modo se abría el texto que además llamaría a los obreros, a los campesinos y a los intelectuales que no estuvieran "envilecidos por la burguesía". ${ }^{19}$

Todo manifiesto identifica su contraparte, establece inauguraciones con un tono beligerante, denuncia y señala como deleznable y superado aquello que pretende abolir. Con la identificación de la audiencia, los manifiestos conducen a un proceso de auto definición de quien lo enuncia, con base en la idealización del interpelado y la negación del contrario. Y es así que se distingue la oposición entre un "nosotros" -que en ocasiones incorpora al "ustedes"- y los "otros", cimentada en la ruptura y la crítica. ${ }^{20}$

19 En el Manifiesto del SOTPE, la burguesía representaba el enemigo común, calificada de explotadora del pueblo y pervertidora del gusto estético, corrompido por influencias extranjerizantes que se habían introducido en los espacios urbanos.

(...) toda manifestación estética ajena o contraria al sentimiento popular es burguesa y debe desaparecer porque contribuye a pervertir el gusto de nuestra raza ya casi completamente pervertido en las ciudades. ${ }^{21}$

20 La afirmación "nuestra raza" implicaba la integración de los artistas a un nosotros abstracto que se articulaba con base en una noción de pueblo, interlocutor idealizado con el cual pretendían dialogar los pintores. El Manifiesto del SOTPE describía al pueblo compuesto por obreros, campesinos, soldados e indios, todos ellos parte de la clase trabajadora y, por lo tanto, sujetos a la explotación de la burguesía. La filiación y simpatías comunistas de varios de los integrantes del sindicato imprimía el tono del 
concepto de lucha de clases en la definición de las posiciones dicotómicas de los sujetos introducidos en el manifiesto. El SOTPE mantuvo vínculos cercanos con el Partido Comunista Mexicano (PCM), e incluso por un momento el comité ejecutivo del partido estuvo encabezado por Siqueiros, Xavier Guerrero y Diego Rivera. ${ }^{22}$ Además, la línea editorial del periódico $E l$ Machete tendía hacia una visión comunista adscrita a la política de Frente Único postulada por la Komintern. En ese sentido, el manifiesto se dirigía a sus interlocutores como "camaradas" y concluía con la consigna: "por el proletariado del mundo". ${ }^{23}$

21 El indígena se articulaba con el obrero y el campesino como parte de las "clases productoras", pero en tanto que indígena se distinguía de éstas; la raza marcaba cierta distancia y entonces era considerado como parte del pueblo pero al mismo tiempo diferente al resto de los sujetos que lo componían. ${ }^{24}$ La raza determinaba entonces la distinción; mientras que el obrero y el campesino eran descritos de acuerdo con sus actividades económicas, el indígena se diferenciaba como parte de una clase particular: la clase indígena.

La catalogación del indígena como clase y el uso indistinto de los términos indio e indígena en el Manifiesto del SOTPE respondía al léxico de la época utilizado para designar a un sector social que de cierto modo se consideraba ajeno. El concepto se había configurado como un singular colectivo que no se expresaba en una sola voz, sino que respondía a la variabilidad polémica de sus acepciones y usos. Incorporaba una serie de denominaciones que habían descrito y clasificado a sujetos colectivos e individuales dispares, aunque aglutinados de acuerdo con una fisionomía, cultura, origen y territorio, que además, coincidente con el de un Estado-nación, lo integraba y tensionaba con proyectos políticos. La designación del indio o el indígena siempre ha sido determinada por la dilucidación de la otredad. El "otro": denominado, explicado, descrito, señalado... ajustado a una perspectiva ajena y apropiado. Su interpretación ha atravesado por diversas circunstancias socio-políticas: las visiones proteccionistas y la catalogación de acuerdo con la pureza de sangre; los debates sobre su supuesta inferioridad y minoría de edad; la denominación adecuada a un sistema jurídico y las disputas en torno a su ciudadanía; la reivindicación de un sistemático sojuzgamiento y su inclusión dentro de un relato historiográfico nacionalista; las aspiraciones de asimilación y aculturación... y un largo etcétera que ha determinado los vínculos entre el designado como indígena y quien lo ha señalado como tal. ${ }^{25}$

24 La categoría indio ha sido utilizada para designar a los pueblos originarios de América, dotada de atributos jurídicos particulares en un sistema de Antiguo Régimen. Paulatinamente, con la estructuración de un Estado-nación mexicano, se dio paso al uso del término indígena, que inicialmente designaba a aquello originario de un lugar sin que en esta acepción mediara la raza. Dentro de un proyecto de nación que pretendía establecer al igualdad jurídica de sus ciudadanos pero que no podía eludir a los grupos sociales con una cultura y una carga histórica particular, el término indígena se introdujo como distintivo, como una designación que apelaba al origen y que de cierto modo pretendía desplazar las estratificaciones raciales a favor de una integración nacional. ${ }^{26}$

25 A decir de Javier Treviño, la nación mexicana se constituyó con base en un "marco de referencia racista", un Estado-nación propiciatorio de la exclusión o el privilegio de acuerdo con la conformación de identidades planteadas en términos raciales. ${ }^{27}$ En este contexto, las acepciones se imbricaron en el concepto de indígena como la designación de 
una otredad homogeneizada en una estructura condensada y distinguida del resto de los sectores sociales.

La sinonimia entre los términos indio e indígena se refleja en el discurso del SOTPE y muestra las tensiones intrínsecas en el uso del léxico de la época. El llamado al pueblo incluía a "la raza indígena humillada" y al "soldado indio" y con ello se establecía una diferenciación con el resto de los interlocutores. La distinción estaba condicionada por la raza, pero no se presentaba en términos biológicos sino con referente en una realidad social e histórica. El manifiesto recurría también a un relato histórico que describía el sojuzgamiento del indígena, reiterando la imagen de una raza doliente que debía ser redimida tras siglos de miseria y explotación. ${ }^{28}$ Los argumentos del SOTPE parecían hacer eco de planteamientos reivindicatorios como el de Manuel Gamio, quien refutaba los asertos que denotaban la inferioridad del indígena y abogaba por su "regeneración", eximido de la opresión de la cual había sido objeto sistemáticamente. ${ }^{29}$

El elogio del indígena elevaba la elegía de la sangre derramada y la miseria de la sujeción y el olvido, al tiempo que apelaba a la memoria, la constancia y la continuidad que se le atribuía como un elemento definitorio de la cultura y la estética mexicana. El Manifiesto del SOTPE cimentaba las particularidades del arte mexicano con un argumento racial que hacía eco de los esfuerzos de asimilación del indígena a la cultura nacional, como agente que evocaba un origen mítico y la dilucidación del carácter del mexicano de acuerdo con las particularidades atribuidas a una raza ${ }^{30}$.

Las disertaciones encaminadas a definir el perfil del mexicano recurrían a una argumentación que observaba la raza como elemento condicionante de la cultura. Durante la primera mitad del siglo XX el "problema del indio" se introdujo en una efervescente mesa de debate que abogaba por las posibilidades de su incorporación a una estructura nacional. Después de la revolución mexicana proliferaron las interpretaciones raciales de la cultura mexicana, las visiones decantadas de las cualidades atribuidas a una raza se imbricaban y tensionaban en la constitución de una idea de nación modelada con base en la etnicidad y la definición de rasgos culturales propios, los cuales además eran pasados por el tamiz de la revolución cubierta con un halo teleológico que dotaba de sentido a la nación. En este contexto, la imagen del indio forjó un campo de dilucidaciones en disputa que circulaban entre la exaltación, la descalificación y el reconocimiento en aras de la asimilación.

La pregunta sobre la mexicanidad del indígena, el rol que asumía dentro de la sociedad y los resabios culturales que el mexicano mantenía como "herencia" produjeron una serie de disertaciones y políticas indigenistas. La valoración del indígena como sector demográfico que debía ser atendido se reflejaba en las acciones que el Estado había emprendido en pos de su integración, como la fundación de la Dirección de Antropología (1917), el Departamento de Educación y Cultura Indígena (1921) ${ }^{31}$ y el programa de Misiones Culturales que formó parte de la campaña civilizatoria promovida por José Vasconcelos. La integración del indígena sería también un tema recurrente en el ensayo de la época, personajes como Andrés Molina Enríquez, Manuel Gamio, José Vasconcelos, Moisés Sáenz, Alfonso Caso Samuel Ramos y Vicente Lombardo Toledano, entre otros, abordaron la situación del indígena como factor explicativo de la realidad mexicana.

Michiel Baud describe el indigenismo como una corriente intelectual latinoamericana que apelaba a la valoración de las culturas indígenas y su asimilación como parte de un proceso de modernización..$^{32}$ Una perspectiva que no partía de la visión de los sujetos que interpretaba, sino del otro, observador, que intentaba dilucidarlos. Dilucidación y 
asimilación. La consigna era integrar y para ello antes había que explicar. En sintonía con los intelectuales y otros artistas de su época, los pintores muralistas se sumaban a las interpretaciones que desde una perspectiva indigenista procuraba reivindicar e incorporar al indio. Las incorporaciones planteadas por este tipo de discursos tendían hacia la supresión mediante la aculturación o la legitimación a partir de la selección, pero siempre planteando una adecuación o transformación de las sociedades y las culturas indígenas. ${ }^{33}$ En el caso del Manifiesto del SOTPE el indígena se concibe fundamentalmente como un elemento legitimador requerido para la definición de la estética mexicana.

Volvamos a la afirmación "nuestra raza" señalada líneas atrás. Hemos explicado de manera general el rol que jugaba el concepto raza en la definición del indígena como un singular colectivo que tensionaba y se ajustaba con contextos socio-políticos. ¿Pero qué tipo de estética se enarbolaba en el manifiesto? Si contraponían el gusto burgués con "el gusto de nuestra raza", ¿qué implicaba esta apropiación asumida con el uso de la primera persona del plural? Y entonces, ¿a qué se referían cuando hablaban de raza?

Sería ocioso pretender encontrar una definición precisa para los conceptos y categorías que Siqueiros utilizó en la redacción del Manifiesto del SOTPE, después de todo los conceptos se encuentran en movimiento a partir de los usos que de ellos hacen los hablantes y a menudo éstos juegan con las posibilidades de los campos semánticos. Sin embargo, es en la variabilidad e imprecisión de los usos que se presentan las problemáticas que permiten dibujar un panorama complejo con respecto a las perspectivas de los actores estudiados.

Los artistas el SOTPE encumbraban al indígena como elemento fundamental de la cultura y la estética mexicana y concebían la facultad artística como un don intrínseco a la raza. Una raza que designaba al otro en tanto que denominado con un singular colectivo distintivo. Un sujeto cuya tradición mantenía resabios de otros tiempos, residuos cuya continuidad se observaban en el pueblo. Un pueblo en abstracto concebido en un sentido romántico que proyectaba imágenes idealizadas y representaba la conciliación de la diversidad. Afirmaban la existencia de una estética popular de tradición indígena cuyo rastro se encontraba primordialmente entre las clases populares, pero que comenzaba a "purificar los medios intelectuales de México"

No solamente todo lo que es trabajo noble, todo lo que es virtud es don de nuestro pueblo (de nuestros indios muy particularmente), sino la manifestación más pequeña de la existencia física y espiritual de nuestra raza como fuerza étnica, brota de él y lo que es más, su facultad admirable y extraordinariamente particular de hacer belleza: el arte del pueblo de México es la manifestación espiritual más grande y sana del mundo y su tradición indígena es la mejor de todas. ${ }^{34}$

El don de producir belleza se consideraba intrínseco a la raza que ahora designaba a otro sujeto: al mexicano, asentado en el pueblo en los términos definidos por el SOTPE, es decir, representado por las clases populares; las clases trabajadoras. Sin embargo, la "fuerza étnica" donde se sustentaba y se sustentaría la estética mexicana se encontraba fincada en la herencia que radicaba en la "estética popular indígena" y que tenía como repositorio al indígena contemporáneo ${ }^{35} \mathrm{El}$ indígena se reconocía como propio, "nuestros indios" o "los indios de nuestros pueblos", parte de una misma comunidad imaginada que sin embargo se distinguía. Distinción de la cual provenía la originalidad del arte mexicano.

Estos planteamientos se encontraban en sintonía con la clasificación que Gamio había hecho sobre el arte mexicano. Diferenciaba el producido en el período prehispánico, las 
"importaciones" de influencias extranjeras a partir de la conquista y los ejemplos de "continuación", es decir, aquellos que mantenían resabios del arte prehispánico y a través de los cuales se incorporaba en las obras mexicanas cierta estética indígena. Encontraba estos ejemplos de continuidad en las manifestaciones artísticas de la "clase indígena" y la "clase media" y abogaba por el acercamiento y el influjo recíproco en pos de la producción de un arte nacional. ${ }^{36}$

La clase indígena guarda y cultiva el arte prehispánico reformado por el europeo. La clase media, guarda y cultiva el arte europeo reformado por el prehispánico o indígena. La clase llamada aristocrática dice que su arte es el europeo puro. Dejemos a esta última en su discutible purismo, por no sernos de interés y consideramos a las dos anteriores. ${ }^{37}$

Gamio utilizaba también la noción de clase para describir al indígena del mismo modo en que fue utilizado por Siqueiros, es decir, como una categoría determinada por la raza. Pareciera entonces que, no obstante las simpatías con un discurso que pugnaba por la lucha de clases, la definición de una clase indígena respondía más que nada a los discursos indigenistas que en la pretensión de asimilar e integrar, distinguían.

Tanto los argumentos de Gamio y del SOTPE apelaban al pasado, a un relato histórico que encumbraba civilizaciones cuya memoria se glorificaba y cuya cultura se reivindicaba como propia. Una línea de sangre que alcanzaba tanto a los indígenas contemporáneos como a los mestizos; a los mexicanos; al pueblo mexicano; al artista. El mismo Siqueiros, en el manifiesto 3 llamamientos de orientación actual a los pintores y escultores de la nueva generación americana, publicado en 1921 en la revista Vida Americana, señalaba un argumento que anticipaba lo proclamado por el SOTPE en relación con la recuperación de la herencia indígena y prehispánica en la conformación de una estética de vanguardia. En este caso llamaba a un acercamiento con una cultura cuya "proximidad climatológica" con el artista le permitiría asimilar "el vigor constructivo de sus obras". Esta aproximación se consideraba un punto de partida de una estética que superaba nacionalismos y que en cambio clamaba por la universalización. Siqueiros afirmaba que la "natural fisionomía racial" del artista aparecería inevitablemente en su obra. La valoración del elemento indígena se asumía como una posible guía, pero que debía ser problematizada para no caer en "lamentables reconstrucciones arqueológicas". ${ }^{38}$

En el mismo sentido, el Manifiesto del SOTPE proponía una estética que tomara la cultura indígena como sustento pero no como fuente única y el artista asimilara al indígena como un elemento cultural que también le era propio en tanto que definitorio de la cultura mexicana; depositado en el pueblo mexicano; incorporado en "su" raza. El Manifiesto del SOTPE sostenía una visión que defendía una permanencia y actualización del pasado que serviría como pauta para la conformación de un arte nuevo. El sustrato ancestral prevaleciente en las manifestaciones populares debía conducir hacia la conformación de un arte cuyo sustento étnico lo potenciaría hasta que lograra compararse con la estética de las "civilizaciones autóctonas", objetivo por el cual los artistas manifestaban que "lucharían sin descanso". ${ }^{39}$ El reconocimiento de una tradición implicaba continuidad dentro de la ruptura, una constancia del pasado a través de la cual se sentaban los cimientos para potenciar el arte que se auguraba. El Manifiesto del SOTPE no proponía la restitución de una estética sino la conformación de un arte distinto que se establecía como escisión ante un paradigma estético, pero que se sostenía en interpretaciones de un sujeto ajeno, aunque incorporado por apropiación. 

elaboraban como un discurso indigenista en los términos planteados por Baud. Finalmente caracterizaban al otro, no obstante lo asumieran como parte de sí al considerarse próximos o incluso herederos de éste. Un indigenismo desde el arte que transitaba entre el discurso y la imagen. En sus memorias, José Clemente Orozco reconoció la importancia del Manifiesto del SOTPE como productor de propuestas estéticas, tales como el "arte proletario" y "cierta vertiente de arte indigenista". ${ }^{40}$ Sin embargo, el manifiesto no significó la pauta, sino el correlato y la base teórica del Muralismo. Los murales de la Preparatoria y la SEP se iniciaron -y en algunos casos concluyeron- tiempo antes de que los artistas publicaran su manifiesto, de modo que el programa estético no se anunciaba como un sugestivo punto de partida sino como un gesto legitimador y reflexivo de un proceso ya puesto en marcha cuyos resultados y problemáticas incidían en la aspiración de un arte imaginado en el mismo sentido y vislumbrado hacia el horizonte. A decir de Jorge Alberto Manrique, el Manifiesto del SOTPE representó "la piedra de toque" que otorgaba sustento teórico al Muralismo Mexicano, a pesar de las discrepancias entre los pintores y no obstante no se ciñeran a cabalidad a las premisas que habían suscrito en el texto programático, como por ejemplo, la renuncia a la pintura de caballete. ${ }^{41}$ proviniera del pueblo y se dirigiera a éste tenían ya un referente tangible, aunque la democratización del arte postulada fuera hasta cierto punto relativa. Renato González Mello ha explicado que el arte público propuesto por los muralistas presentaba dos niveles de significación: uno esotérico, vinculado con simbolismos inteligibles solamente para un grupo de iniciados; y otro exotérico, acorde con el objetivo didáctico planteado en el programa del sindicato que clamaba por la constitución de un arte del pueblo y para el pueblo..$^{42}$ En el mismo sentido resulta cuestionable la inteligibilidad del discurso doctrinario y las proposiciones teóricas vertidas en un texto que llamaba al pueblo.

\section{Consideraciones finales}

41 En el Manifiesto del SOTPE se establecía una distinción, pero también una apropiación y asimilación en relación con el elemento indígena. La interpretación que los artistas realizaban con respecto al indígena se movía entre distintos niveles. La idea de una cultura particular subyacente en el indígena y éste como sustrato del arte y la cultura mexicana lo ubicaba como elemento inherente y definitorio de la mexicanidad, pero al mismo tiempo justificaba una relación vertical de adoctrinamiento y asimilación de un sector social y cultural. Pues el indígena imaginado se configuraba históricamente a partir de una memoria del pasado elogiado y una imagen de un sujeto que debía incorporarse conscientemente a la cultura por medio del arte.

El indígena llevaba consigo una memoria y un bagaje cultural, una carga histórica que se concebía como inherente a la raza. Pero además se trataba de un sujeto interpelado, un actor social descrito y "llamado" en el manifiesto. Se enunciaba como un sujeto colectivo, un concepto cuya semántica oscilaba entre temporalidades, pues apelaba a un sujeto histórico cuyo devenir partía de un pasado remoto que, aunque lejano en el tiempo, mantenía cierta continuidad y permanencia como un sustrato subyacente en la cultura. Como una proclama estética y política, el Manifiesto del SOTPE interpretaba al indígena en relación con del entorno social, como elemento constitutivo del arte mexicano; un actor político y un sustrato que particularizaba y daría forma a la estética mexicana. Se 
convertía entonces en un emblema de una identidad construida por apropiación, redimido con una condición de perennidad que se establecía como un sustrato subyacente y definitorio de la cultura y que le otorgaba a esta un sentido de continuidad. El Manifiesto del SOTPE interpretaba el sentido artístico del mexicano como un elemento cultural que debía ser vitalizado. Se proponía la institución de una estética que entrañaba cierta reciprocidad articuladora de la sociedad fincada en la permeabilidad de un rasgo cultural que traspasaba las fronteras entre los sectores sociales.

Al incorporar al indígena como un actor perteneciente al pueblo aunque distinto, el manifiesto mostraba las problemáticas en torno a la raza y la posición del indígena con respecto a otros actores sociales. Entre las interpretaciones sobre el indígena vertidas en el Manifiesto del SOTPE se establece un juego entre el indígena como concepto y como actor social e histórico. El indígena como un singular colectivo que encerraba un pasado histórico y una posición social determinada por la raza; como un elemento cultural abstracto apropiado y asimilado; como un sujeto colectivo homogeneizado que planteaba tensiones en la pretensión de integrarlo; el indígena como propio y extraño.

\section{BIBLIOGRAFÍA}

ACEVEDO, Esther, "Procesos de quiebre en la política visual del México posrevolucionario" en La búsqueda perpetua: lo propio y lo universal de la cultura latinoamericana, Secretaría de Relaciones Exteriores, México, 2011.

ALFARO Siqueiros, David, “3 llamamientos de orientación actual a los pintores y escultores de la nueva generación americana” en Vida Americana Nº 1, Barcelona, 1921.

http://icaadocs.mfah.org/icaadocs/ELARCHIVO/RegistroCompleto/tabid/99/doc/801659/ language/es-MX/Default.aspx (Consulta: 20/03/2018)

BAUD, Michiel, Intelectuales y sus utopías. Indigenismo y la imaginación de América Latina, Centro de Estudios y Documentación Latinoamericanos, Amsterdam, 2003.

BÜRGER, Peter, Teoría de la vanguardia, Ediciones Península, Barcelona, 2000.

CASTELLANOS, Alicia, “Asimilación y diferenciación de los indios en México”, en Estudios Sociológicos № 34, El Colegio de México, México, 1994, http://www.jstor.org/stable/40420259. (Consulta: 23/03/2018)

CHARLOT, Jean, El renacimiento del muralismo mexicano, 1920-1925, Domés, México, 1985.

DA SILVA, Cristhian Teófilo, "Indigenismo como ideología e prática de dominaçao: apontamentos teóricos para uma etnografía do indigenismo latino-americano em perspectiva comparada", en Latin American Research Review № 1, Vol. 47, The Latin American Studies Association, 2012, http://www.jstor.org/stable/41413328. (Consulta: 23/03/2018)

GAMIO, Manuel, Forjando Patria, Porrúa, México, 1916.

GELADO Viviana, Poéticas da transgressao. Vanguarda e Cultura Popular nos anos 20 na América Latina, Editora 7Letras, Rio de Janeiro, 2006. 
GONZÁLEZ MELLO, Renato, José Clemente Orozco. La pintura mural mexicana, CONACULTA, México, 1997.

GONZÁLEZ MELLO, Renato, La máquina de pintar, UNAM, México, 2008.

MANRIQUE, Jorge Alberto, Arte y artistas mexicanos del siglo XX, CONACULTA, México, 2000.

MANRIQUE, Jorge Alberto, Una visión del arte y la historia, Tomo IV, UNAM, México, 2007.

OROZCO, José Clemente, Autobiografía, Era, México, 1981.

ORTEGA, "La pintura y la escultura en México en 1922" en El Universal Ilustrado, Año VI, N 924, 1922.

PUCHNER, Martin, Poetry of the Revolution: Marx, Manifestos and the avant-gardes, Princeton University Press, Princeton, 2006.

RAMÍREZ, Mari Carmen, "Desplazamiento de utopías" en Versions and inversions. Perspectives on Avant-Garde Art in Latin America, The Museum of Fine Arts, Houston, Houston, 2006.

RAMÍREZ Zavala, Ana Luz, “Indio/Indígena, 1750-1850”, en Historia Mexicana № 3, Vol. 60, El Colegio de México, México, 2011, http://www.jstor.org/stable/41151295. (Consulta: 07/10/2017)

REYNOSO Jaime, Irving, "Manuel Gamio y las bases del indigenismo en México" en Andamios № 22, Vol. 10, Universidad Autónoma de la Ciudad de México, México, 2013.

http://www.scielo.org.mx/scielo.php?script=sci_arttext\&pid=S1870-00632013000200017 (Consulta: 29/09/17)

RODRÍGUEZ Mortellaro, Itzel, “Arte Nacionalista e indigenismo en México en el siglo XX. El renacimiento de la mitología indígena antigua en el Movimiento Muralista” en México y España: huellas contemporáneas. Resimbolización, imaginarios, iconoclastia, Universidad de Murcia, Murcia, 2010.

RODRÍGUEZ Prampolini, Ida, Muralismo Mexicano, 1920-1940. Catálogo razonado I, FCE-UNAM-UVINBA, México, 2012.

Sindicato de Obreros Técnicos, Pintores y Escultores, "Manifiesto del Sindicato de Obreros Técnicos, Pintores y Escultores”, El Machete № 7, México, 1924.

TENORIO, Mauricio, Artilugio de la nación moderna. México en las exposiciones universales 1880-1930, Fondo de Cultura Económica, México, 1998.

TREVIÑO Rangel, Javier, “Racismo y Nación: comunidades imaginadas en México”, Estudios Sociológicos № 78, Vol. 26, El Colegio de México, México, 2008.

http://www.jstor.org/stable/40421178. (Consulta: 23/03/2018)

UNRUH, Vicky, Latin american vanguards. The art of contentious encounters, University of California Press, Berkeley, 1995.

VENKO, Kanev, "El manifiesto como género. Manifiestos independentistas y vanguardistas", América: Cahiers du CRICCAL № 21, 1998, DOI : https://doi.org/10.3406/ameri.1998.1357 (Consulta: 15/05/2015)

\section{NOTAS}

1. SOTPE, 1924:4

2. Manrique, 2007: 211. 
3. Ortega, 1922: 30.

4. Charlot, 1985: 283.

5. Acevedo, 2011:33.

6. Puchner, 2006:4.

7. Bürger, 2000.

8. González, 1997: 16-20.

9. Ramírez, 2006: 122.

10. Gelado, 2006: 31.

11. Gelado, 2006: 113.

12. Del Conde, 1989: 209.

13. Charlot, 1985: 43.

14. SOTPE, 1924: 4.

15. SOTPE, 1924: 4.

16. Rodríguez Prampolini, 2012.

17. Rodríguez Mortellaro, 2010.

18. Kanev, 1998: 11.

19. SOTPE, 1924: 4.

20. Unruh, 1995: 89.

21. SOTPE, 1924: 4.

22. Lear, 2006: 115.

23. SOTPE, 1924: 4.

24. SOTPE, 1924: 4.

25. Ramírez, 2011; Castellanos, 1994; da Silva, 2012.

26. Ramírez, 2011: 1675.

27. Treviño, 2008: 673 y 676.

28. SOTPE, 1924: 4.

29. Gamio, 1916: 21-26.

30. Tenorio, 1998: 321.

31. Reynoso, 2013.

32. Baud: 2003, VI-VII.

33. Da Silva, 2012: 19.

34. SOTPE, 1924: 4.

35. SOTPE, 1924: 4.

36. Gamio, 1916: 40.

37. Gamio, 1916: 39.

38. Siqueiros, 1921: 3.

39. SOTPE, 1924: 4.

40. Orozco, 1981: 66.

41. Manrique, 2000: 17.

42. González, 2008: 15. 


\section{RESÚMENES}

El Sindicato de Obreros Técnicos, Pintores y Escultores (grupo que reunía a los protagonistas del Muralismo Mexicano) publicó un manifiesto que daba sustento teórico a la pintura mural, pero además contenía interpretaciones sobre el indígena. Éste era representado como un elemento subyacente en el arte mexicano, pero también como un sujeto interpelado de acuerdo con la proclama estética y política que se enunciaba en el manifiesto. Este artículo describe la manera en que se proyectaron ciertas imágenes del indígena en el discurso de los pintores muralistas como uno de los ejes de las proposiciones de su manifiesto.

Le Syndicat d'Ouvriers Techniques, Peintres et Sculpteurs (le groupe qui réunissait les protagonistes du Muralisme Mexicaine) a publié un manifeste qui donnait un soutien théorique à la peinture murale et qui contenait des interpretations sur l'indigène. Celui-ci était représenté comme un élément sousjacent dans l'art mexicain, mais aussi comme un sujet interpellé conformément à la proclamation esthétique et politique qui était énoncée dans le manifeste. Cet article décrit la manière avec laquelle certaines images de l'indigène ont été projetées dans les discours des peintres muralistes comme l'un des axes des propositions de son manifeste.

\section{ÍNDICE}

Mots-clés: indigène, art mexicaine, Muralisme Mexicaine, manifeste, Syndicat d'Ouvriers Techniques, Peintres et Sculpteurs

Palabras claves: indígena, arte mexicano, Muralismo Mexicano, manifiesto, Sindicato de Obreros Técnicos, Pintores y Escultores.

\section{AUTOR}

\section{SUREYA ALEJANDRA HERNÁNDEZ DEL VILLAR}

Posgrado en Historia del Arte - Universidad Nacional Autónoma de México. 